Table 1. The mean, minimum and maximum levels of blood

\section{MINERAL STATUS IN BLOOD SERUM OF DOMESTICATED ELEPHANTS (ELEPHAS MAXIMUS) AND CERTAIN PLANTS OF SRI LANKA}

\section{Ashoka Dangolla, A.G. Malitha and Indira Silva}

Faculty of Veterinary Medicine and Animal Science, University of Peradeniya, Sri Lanka

In addition to bringing in foreign currency through tourism, the domesticated elephants in Sri Lanka play important roles in cultural, religious and ceremonial functions, of high value to the Island. In Sri Lanka, disease diagnosis and treatment of domesticated elephants is largely done using indigenous medical methods, as in India (Gokula \& Varadharajan, 1996). The present day domesticated elephant population is rapidly declining mostly due to old age. The knowledge on management, nutrition and common diseases of domesticated elephants is important in order to provide better medical attention. The present pilot investigation was conducted to measure serum levels of some selected minerals namely, sodium, potassium, calcium, magnesium and phosphorous in domesticated elephants. It was also decided to measure the levels of these minerals in leaves and bark of Coconut (Cocos nucifera), Jak (Artocarpus heterophyllus) and Kitul (Caryota urens), which are commonly included in diets of captive elephants in Sri Lanka. Blood and plant samples were taken from three districts -- Kandy, Matara and Colombo, in the central, southern and western provinces, respectively, of Sri Lanka.

Blood samples from 15 domesticated elephants belonging to private owners were collected from the ear vein during September 2000 to March 2001. Samples were transported on ice to the laboratory within 24 hours, serum was separated and stored at $-20^{\circ} \mathrm{C}$ until analyzed. Sodium and potassium levels in serum were analyzed by the colorimetric determination using commercial kits from Stanbio laboratory, 2930 East Housten street, San Antonio, Texas. Serum calcium, inorganic phosphorous and magnesium levels were determined by colorimetric methods using commercial kits by Randox Laboratories Ltd., United Kingdom. The sodium, potassium, calcium and magnesium levels of duplicate samples of leaves and bark of coconut, jak and kitul were measured according to dry ashing method (AOAC, 1995) using atomic absorbance.

Serum sodium, potassium, calcium, magnesium and serum minerals in 15 domesticated elephants in Sri Lanka

\begin{tabular}{llll}
\hline Mineral & Minimum & Maximum & Mean \\
\hline Sodium mM/L & 116.7 & 141.7 & 130.8 \\
Potassium Mmol/L & 4.2 & 7.1 & 5.5 \\
Calcium mg/L & 9.1 & 12.2 & 10.6 \\
Magnesium mg/L & 1.4 & 2.4 & 1.8 \\
Phophorous mg/L & 3.1 & 6.0 & 4.3
\end{tabular}

phosphorus levels in the 15 domesticated elephants are depicted in Table 1. Mean and range of sodium, potassium, calcium and magnesium levels in coconut, jak and kitul from the three districts in Sri Lanka are summarized in Table 2. Coconut, which constitutes a substantial proportion of the diet, is rich in sodium. The reason for relatively high levels of sodium in coconut from Matara and Colombo compared to Kandy may be that the two districts are in the coastal areas of the country in which the soil may be rich in salt, whereas Kandy is in the central hills. The serum sodium levels in domesticated elephants were higher compared to that in wild elephants, possibly due to differences in diets (Silva \& Kuruwita, 1993a). This may be one of the reasons why wild elephants are known to prefer water and soils rich in sodium (Dierenfeld, 1994) to meet their requirement of sodium even at the expense of breaking into kitchens of village folk. However, recent reports from India show that the diets of domesticated Indian elephants may be deficient in sodium (Sreekumar \& Nirmalan, 1989).

It is unexpected to find low serum potassium levels in domesticated elephants compared to wild elephants (Silva \& Kuruwita, 1993a), as their daily diet essentially contains kitul; a food rich in potassium. The requirements of potassium may be met better by jak compared to coconut (Nair \& Ananthasubramanium, 1979). Our findings on serum calcium values are comparable to those reported earlier on domesticated elephants in Sri Lanka (Silva \& Kuruwita, 1993b). The requirement of calcium, the only mineral in which a deficiency has been reported in elephants (Dierenfeld, 1994), is 8-9g/day/tusker (McCullar, 1994). The elephants mainly fed on coconut leaves could be deficient in calcium as coconut leaves are poor in calcium. Jak appears to have the highest level of calcium. Serum magnesium values for domesticated or wild elephants in Sri Lanka are not available for comparison. Blood levels of phosphorous were comparable with published values for wild elephants in Sri Lanka (Silva \& Kuruwita, 1993a).

It is apparent, that the habit of providing only coconut leaves to domesticated elephants, as done in modern "elephant safaris" is unsatisfactory. Providing only kitul as a food item which is becoming scarce (Karunarathna \& Ranawana, 1999) may not be adequate to meet the demands of minerals especially in growing

Table 2. Sodium, potassium, calcium and magnesium content (g/kg dry matter) of Coconut, Jak and Kitul collected from three districts in Sri Lanka and their mean, minimum and maximum values.

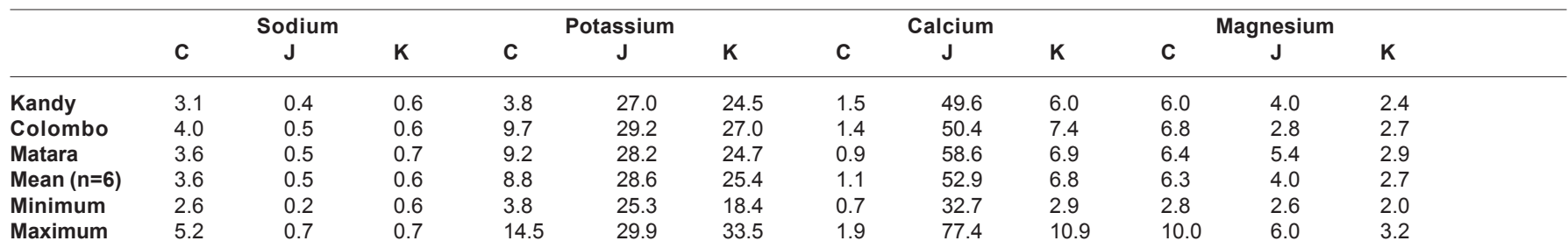

C - Coconut (Cocos nucifera); J - Jak (Atocarpus heterophyllus); K - Kitul (Karyota urens) 
elephants (Nair \& Ananathasubramanium, 1979). A mixture of herbage including grasses may be an alternative diet (Karunarathna \& Ranawana, 1998). Perhaps, a diet formulation for different age groups of elephants is a timely necessity. An island-wide study on nutrient status of working and nonworking domesticated elephants of all ages, is urgently needed for better understanding of the serum levels of minerals with respect to their diets. Similar investigations conducted in domesticated elephants in other countries have been of immense clinical value (Sreekumar \& Nirmalan, 1989).

\section{REFERENCES}

AOAC Internationals (1998). Official method of analysis of AAAT international Inc.. Journal of the Association of Official Agricultural Chemists. $16^{\text {th }}$ Edition.

Dierenfeld, E.S. (1994). Nutrition and feeding. In: Mikota S.K., S.E.L. Sargent and G.S. Ranglack (Editors). Medical Management of the Elephant. Indira Publishing House, Michigan.

Gokula, V. and M. Varadharajan (1996). Status of temple elephant management in Tamil Nadu, southern India. GAJAH 15: 37-40.

Karunarathne, S.H.P.P. and K.B. Ranawana (1998). A preliminary study of the food preference of domesticated elephants (Elephas maximus L.) in Sri Lanka. Ceylon Journal of Science (Biological Sciences) 25: 58-64.

Karunarathne, S.H.P.P. and K.B. Ranawana (1999). A preliminary study on feeding activity patterns and budgets of domesticated elephants (Elephas maximus maximus) in Sri Lanka. Ceylon Journal of Science (Biological Sciences) 27(1): 61-65.

McCullar, M. (1994). Dentistry. In: Mikota S.K., S.E.L. Sargent and G.S. Ranglack (Editors). Medical Management of the Elephant. Indira Publishing House, Michigan.

Nair, V.B. and C.R. Ananthasubramanium (1979). Studies on the nutritional requirements of the elephant (Elephas maximus). Indian Veterinary Journal 56: 667-671.

Silva, I.D. and V.Y. Kuruwita (1993a). Hematology, plasma and serum biochemistry values in domesticated elephants (Elephas maximus ceylonicus) in Sri Lanka. Journal of Zoo and Wildlife 24(4): 440-444.

Silva, I.D. and V.Y. Kuruwita (1993b). Hematology, plasma, and serum biochemistry values in free-ranging elephants (Elephas maximus ceylonicus) in Sri Lanka. Journal of Zoo and Wildlife 24(4): 434-439. Sreekumar, K.P. and G. Nirmalan (1989). Mineral status in the blood of Indian elephants. Indian Journal of Animal Science 59(10): 1253-1258.

\section{ACKNOWLEDGMents}

K.R.J.K. Amararathna, M.R.C.K. Mallawa and S. Deegala of University of Peradeniya, Dr. S.S.P. Susil, R. Ariyarathna, J.K. Gunarathna and R.G. Jayathissa of Veterinary Research Institute, Gannoruwa are acknowledged for their technical assistance. This project was partially funded by RG/ 2000/83/V of University of Peradeniya.

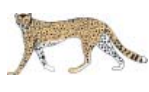

\section{NEW RECORD}

ZOOS' PRINT JOURNAL 19(7): 1550

\section{STATILIA NEMORALIS (SAUSSURE) (INSECTA: MANTODEA) FROM MAHARASHTRA}

\section{P.M. Sureshan ${ }^{1}$, H.V. Ghate ${ }^{2}$ and C. Radhakrishnan ${ }^{3}$}

${ }^{1}$ Western Regional Station, Zoological Survey of India, Pune, Maharashtra 411044, India

${ }^{2}$ Department of Zoology, Modern College, Shivajinagar, Pune, Maharashtra 411005, India

${ }^{3}$ Western Ghats Field Research Station, Zoological Survey of India, Kozhikode, Kerala 673002, India

web supplement

The genus Statilia Stål (Mantodea: Mantidae) comprises three species in India, namely., S. maculata (Thunberg), S. apicalis (Saussure) and $S$. nemoralis (Saussure). Out of these, $S$. maculata has a wider distribution in the country. Though a common species of Oriental Asia, S. nemoralis has so far been known only from Arunachal Pradesh, Tamil Nadu and West Bengal (Mukerjee et al., 1995). During the faunistic survey of Tadoba-Andhari Tiger Reserve $\left(20^{\circ} 25^{\prime} 50^{\prime \prime}-20^{\circ} 04^{\prime} 53^{\prime \prime N} \& 79^{\circ} 33^{\prime}\right.$ 34"E) in Chandrapur District of Maharashtra, a female specimen of $S$. nemoralis (Image $1^{\mathrm{w}}$ ) was collected under light near the Tadoba Rest House. S. nemoralis is the only green coloured species in the genus and the present specimen has a smoky brown patch on the hind wing at the extreme outer end of the costal area. The present report extends the range of $S$. nemoralis to the northwestern part of the Deccan Peninsula. Outside India, the species is known from Eastern Asia and the Philippines. With the present record, 52 species of mantids are known to occur in Maharashtra (Ghate \& Ranade, 2002;
Sureshan et al., in press).

Material examined: One female, 4.xii.1996, Tadoba Rest House, Tadoba-Andhari Tiger reserve, coll. R.M. Sharma (under light) (ZSI-WRS, Pune E/3577).

Measurements: Total length: $45 \mathrm{~mm}$, prozona $5 \mathrm{~mm}$, metazona $10 \mathrm{~mm}$, forecoxa $10 \mathrm{~mm}$, femora $14 \mathrm{~mm}$, tibia $6 \mathrm{~mm}$, forewing $34 \mathrm{~mm}$, hind wing $31 \mathrm{~mm}$.

Description: Body green, abdomen brownish; frontal sclerite sinuate on either side; lateral edges of prozona and metazona denticulate; prosternum without any black patch; fore coxae with five white spines; femora with four external and four discoidal spines, the third largest; claw groove yellow, situated distally, with a black patch proximal to it, larger internal spines blackish at tips and marked at base by black spot; forewing longer than abdomen, stigma without black spot, costal area opaque; hind wing with smoky brown patch at outer corner of costal area.

\section{REFERENCES}

Mukherjee, T.K., A.K. Hazra and A.K. Ghosh (1995). The mantid fauna of India (Insecta: Mantodea). Oriental Insects 29: 185-358.

Ghate, H.V. and S.P. Ranade (2002). Biodiversity of mantids (Insecta: Mantodea) in Pune (Western Ghats) with notes on other regions of Maharashtra. Journal of the Bombay Natural History Society 99(2): 348-352.

Sureshan, P.M., H.V. Ghate and C. Radhakrishnan (in press). Insecta: Mantodea. Fauna of Conservation Area Series: Fauna of Pench National Park. Zoological Survey of India.

\section{ACKNOWLEDGEMENTS}

The authors are grateful to Dr. J.R.B. Alfred, Director, Zoological Survey of India, Kolkata and the Officer-in-Charge, Zoological Survey of India, Pune for facilities and encouragement.

${ }^{w}$ see Image of this mantid on the web at www.zoosprint.org 